\title{
Picturing Hybrids - Hybrid Creatures in Staged Photography
}

\author{
Maja Tabea Jerrentrup \\ School of Film \& Media, Ajeenkya DY Patil University, Pune, Maharashtra, India \\ * E-mail of the corresponding author: maja.jerrentrup@adypu.edu.in
}

\begin{abstract}
Hybrid creatures are among the favourite topics in (amateur) model photography, the most popular are humans with antlers or horns, with a fishtail, and with wings. After looking at typical associations with these creatures, the focus is on embodiment: modelling takes place in a "hybrid" situation that feels like gaining and losing control, that mixes personal expression and acting. By staging themselves as hybrid creatures, models often express a feeling of otherness, make a statement about social inequality, deal with their sexual identity, and can even find redemption through overcoming the body.
\end{abstract}

Keywords: Photography, Staging, Embodiment, Corporeality, Identity, Hybridity, Gender

DOI: $10.7176 / \mathrm{JPCR} / 49-04$

Publication date:June 30th 2020

\section{Introduction}

Humans have always been fascinated by hybrid beings, creatures that are half-human and half-animal (for the history of anthropomorphism see Naumov 2013). This might date back to the discoveries of fossils that early humans could not categorize, or to encounters with different cultures that did not fit into their own categories. The mix of human and animal traits frequently stands for specific powers so that such creatures have been worshipped or admired: hybrids possess abilities that humans do not have, can fly or live underwater, are particularly strong, and can make experiences that remain impossible for humans. Consequently, they continue to intrigue us as Akgün Comak and Pembecioglu show with regard to the mermaid: "animation films, toys and even [in] electroniccomputer games some kind of 'mermaidization' syndrome is developed" (Akgün Comak and Pembecioglu 2018, 156f.). At the same time, they can make us feel uncomfortable, eventually, as they embody the uncanny (see MacDorman and Entezari 2015). "ᄀSince the Renaissance, the most common cognate and eventual alternate for ugliness was 'grotesque.' The word derived from the Italian grottesche (itself from 'grotto,' cave), a term that designated the fantastic decorative designs discovered in 1480 on the walls of underground, grottolike vaults of ancient Roman temples, baths, and palaces. In the eyes of classicists, these otherwise pleasingly innocuous decorative hybrids of implausibly and ambiguously intertwined vegetal, animal, and human elements embodied the transgressive character of ugliness: they exemplified an 'ars combinatoria' or 'species of confusion' that flouted natural law, befuddled reason, and offended decorum. Hybrid conflations resulting in monstrous, unnatural, indeed degenerate creations became one of the prime sites of ugliness" (Athanassoglou-Kallmyer 2018, 32).

Mermaidization and monstrosity - hybrid creatures often evoke strong emotions, the recipient is "split between envy and pity" (Barounis 2016, 192), admiration and disgust. However, hybridity becomes increasingly relevant in our reality. "Considering the degree to which modern technology can now intervene in nature, which ranges from creating new species to replacing body parts and functions, but also taking into account the exploration of the notion of 'hybrids' by contemporary artists, the significance of the discussion [...] becomes evident" (Gartziou-Tatti et al. viii): Hybrids are no more only fictional, but become thinkable which might trigger an even more intense preoccupation with them.

\section{The scene of model photography}

My analysis takes place against the background of the model photography scene ${ }^{1}$, in which hybrid creatures rank among the most popular topics. Modelling refers to pop culture and both influence each other. The scene can be assumed as a visual avant-garde: more than once I noticed that dress elements and topics popular in model photography soon after made it into the mainstream, e.g. floral headdresses, shiny leggings that resemble latex, the enhancement of eyebrows etc. The (amateur) model photography scene in the German-speaking areas (Germany, Austria, parts of Switzerland) where the research was conducted comprises around 400,000 to 600,000 members who are enthusiastic about staged photography, usually in the role of the recipient as well as model, photographer, designer, or make-up artist. Whereas some members make their living on photographing or being photographed, most consider it as their hobby.

The internet, especially the social media, are of special importance for this scene: Here, shootings are

\footnotetext{
${ }^{11}$ I use the term "scene" instead of subculture, as "-sub" implies a hierarchy that I want to avoid. Further, following Dick Hebdige, subcultures are understood as a subversion to normalcy which is not (that) obvious in our context. As we will explore, the scene has in some ways rather individualistic tendencies and is not (primarily) meant to bring together people who feel neglected by the mainstream society. However, identity plays an important role, just as in subcultures.
} 
organized and results are presented and discussed. Social media can be understood as "highly interactive platforms via which individuals and communities share, co-create, discuss, and modify user-generated content. Given the tremendous exposure of social media in the popular press today, it would seem that we are in the midst of an altogether new communication landscape" (Kietzmann et al. 2011, 241). According to Jan Kiezmann and his colleagues, social media fulfil various functions: they help to show presence, to share content, to build relationships, to communicate identity, to engage in conversations, to form groups, and to work on individual or group-related reputation (see 2011, 243). Due to their ubiquity, social media are said to be "an unmatched resource for research" (Miller 2014, 1), especially "important [...] for those who study geographically disparate or hard to reach populations" (Darwin 2017, 321).

In December 2019, I conducted two identical surveys on Facebook in two groups dedicated to model photography, one more in the field of fantasy photography, the other one rather general. 94 people took part in it. In the surveys, I asked which hybrid creatures have been embodied by the models so far (as poll) and, as a second, optional question, why they are fascinated by these hybrids. To avoid ethical dilemmas, I have noted that I would like to use the data for a study. People could tick several options. About one third answered the optional question as well. To enable people to answer more privately I gave them the possibility to contact me via mail, which was used by several participants. The vast majority of participants were women (around 90\%), among the men answering were few photographers (even though my question referred to models), two male models, as well as one transgender person. I estimate the age of the participants between 18 and 45 years.

The result of the survey shows that three creatures in particular are often embodied: hybrids with fishtails (42), with antlers or horns (58), and with wings (42). These were the categories I had added myself based on my experience within the scene. The category "vampires", also added by myself, was surprisingly unpopular (11), eventually as the vampire-hype triggered by some movies and serials is over by now. People were allowed to add own categories and some did so; however, these categories were much less popular.

However, it should be mentioned that research in Facebook groups can bear some disadvantages: as an open survey, people see what has been selected and written before; consequently, social desirability can come into play. Furthermore, myself as the person who has set up the poll can influence the answers. Therefore, as a second method, I rely on more than 10 years of participant observation in the scene. My analysis focuses on a pop-cultural understanding, i.e. the perspective that prevails in the scene. It is also grounded in numerous conversations and informal interviews with models during photo shoots. The emphasis will be not only on the fascination for the hybrids, but also on the embodiment of the creatures

\section{Popular hybrid creatures}

Before I consider embodiment, I will briefly introduce the respective creatures. However, one question must first be addressed: the vast majority of the participants in my survey were female — so are hybrid beings female? Of course, the answer is "no," as literature, religion, and mythology know many male creatures, including the centaurs from Greek mythology or the Hindu god Ganesh. The data of the survey obviously originate from the fact that modelling is a rather feminine domain; yet, it is striking that the three most frequently mentioned hybrids are presented and imagined primarily as female.

In various cultural contexts women have often been associated with animals. Lane writes that it is a way to achieve alienation "comparing them with all that is lowly and venial" (Lane 2018, 106) and gives examples from different European languages in which terms from the animal kingdom are used pejoratively for women. However, this aspect should be kept in mind when looking at the creatures described, and will be examined in more detail below. Besides, decoding cultural artefacts is a learned cultural practice. As such, it is permeated by the web of norms in and from which it was learned-including (hetero)normative conceptions of gender and sexuality(ies) (see Frasl 2018, 202, see also Bryne/McQuillan 1999, 1f.).

\section{1 ... with antlers or horns}

There are many species in the animal kingdom where both males and females carry horns, but those of females are often smaller and less strong while those of males look more magnificent. With the deer/stags that differ from other horn-bearers, antlers normally are carried only by males. Horns are charged with a multitude of often conflicting meanings (see Herzfeld 1984, 443); but they "have a basically positive character. Commonly they signify fertility. Horns are identified with the crescent moon, which signifies fertility both in the basic idea of growth and through its association with menstruation. They are associated with the phallic serpent and with the mighty procreative power" (Russell 1977, 68f.). The Hindu god Shiva for example can take both the form of a bull and a lingam. Horns are also associated with the sun's rays and serve as a symbol for power, but at the same time for danger and for "the fundamental, mysterious, and frightening otherness of animals" (Russell 1977, 70). So it seems conclusive that the devil is traditionally represented with horns, even more, as an extreme hybrid creature that, in addition to its horns, also has horse feet and a tail. This depiction of the devil has lasted for centuries (see e.g. Gogol 2003, 20) and was probably inspired by depictions of the Greek god Dionysos matching the association 
of fertility or rather uncontrolled sexuality as typical for Dionysos's cults. However, the lord of the darkness is imagined as masculine (just as the god of light, see Russell 1977, 117).

The term "horned" can also be found in everyday language: the person whose partner cheats on her is "horned". The exact origin of this expression is unclear, but could be possibly interpreted as a double phallus symbolism. A direct comparison with the animal kingdom is also conceivable, the good nature of an ox stands for that of a betrayed man or the lust of a billy goat for the fraudster. Typically, this expression is applied to men.

Yet, women with antlers or horns are quite omnipresent on social media-mainly because of smart phone filters that can endow portraits with horns and a dark snout instead of the nose. Since such "deer filters" are often marketed as part of make-up filters, it can be assumed that they are primarily aimed at women. Usually, they also come in combination with other female signifiers such as flowers or enlarged eyes (e.g. in the app "Beauty Plus"). How could such filters become so popular? The notion of the powerful, the devilish, or the "horned" does not seem to be stressed in these cute looking filters. There are several sources for women with horns from all over the globe and I will just mention a few: in Lakota mythology, such a creature is known as the Double Woman, a mythical figure that represents dualism and sexual ambiguity and in modern tradition is associated with masculine or lesbian women (Busatta 2016). In the Philippines, folk stories inspired Cecilia Manguerra Brainard to write the famous short story "Woman with horns". Modern anime comics or movies occasionally show women with horns: "One form that tends to intrigue a lot of anime lovers is when girls straddle the line between human and something... more demonic [...] Yet, horned girls aren't any less adorable or cute than a normal girl" (Aaron 2018). Another female figure with horns has recently fuelled the imagination: in 2014, the Disney movie Maleficent came out. Following the Disney tradition, it uses a well-known fairy tale, the Sleeping Beauty. At first glance, Maleficent is the antagonist of Princess Aurora. But the story unfolds differently than Disney's Sleeping Beauty version of 1959: Maleficent does not simply embody the evil, but is a complex figure whose motivations are experienced throughout the story. Thus, the movie and the figure Maleficent criticize Disney's typical visions of perfect women, of the "idealization and romanticization of female passivity and submission" (Frasl 2018, 201). In Maleficent, a man from the patriarchal human realm abuses the fairy queen's trust and cuts off her wings, a crime that makes Maleficent an evil fairy. From her own insight, however, she turns back to the good. The kiss of true love that saves Aurora is not the kiss of a prince, but the platonic kiss of Maleficent. So she is both heroine and villain. Numerous aspects of old narrative traditions are ironically taken up, such as the immortal love at first sight. Consequently, Maleficent can be understood as "a postmodern strategy of retelling, retelling, and changing" (Frasl 2018, 214f.).

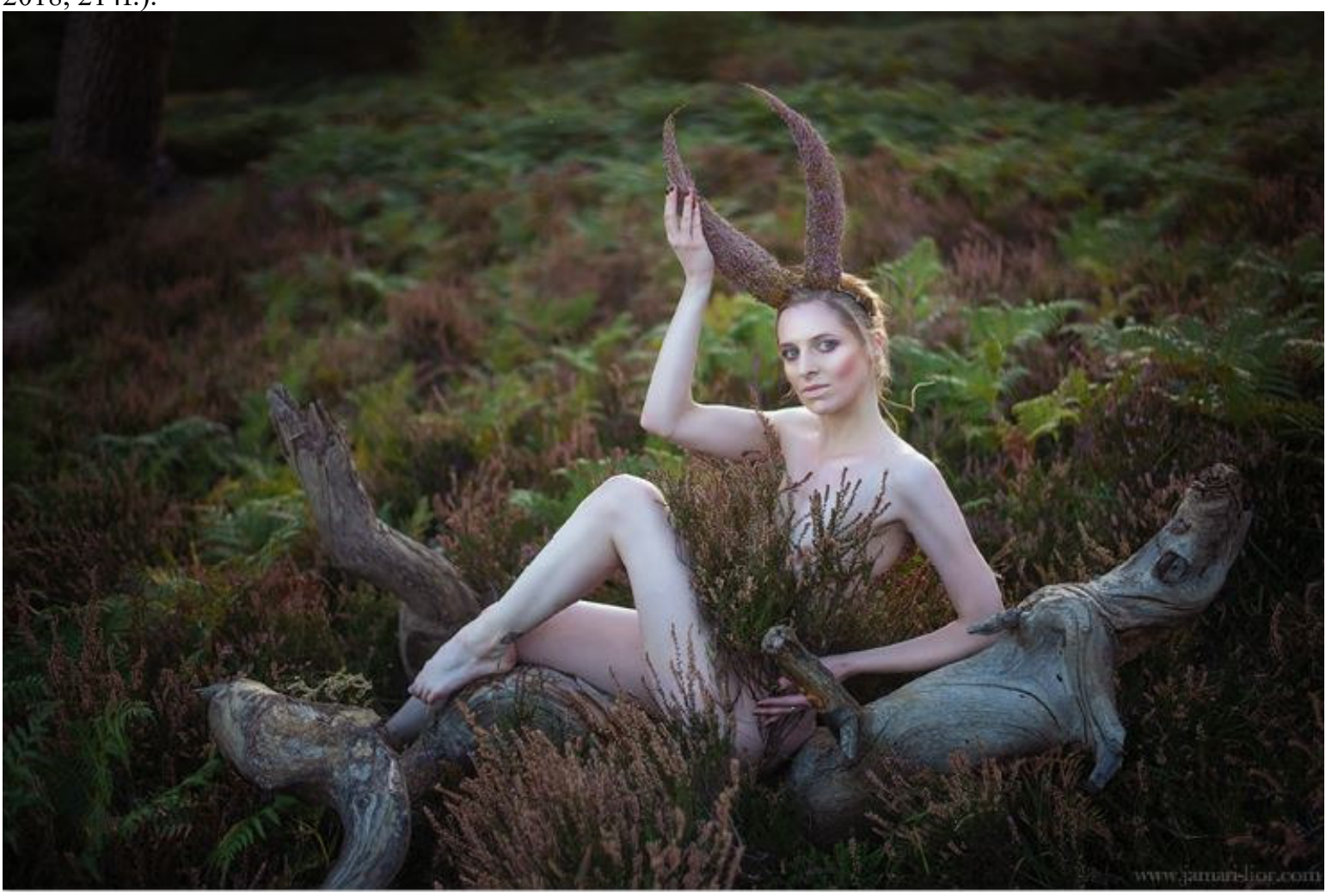

Fig.1: Model Carmen, styling by Der Blütenwald, make-up by Eva Hinsken-Ebbing. 


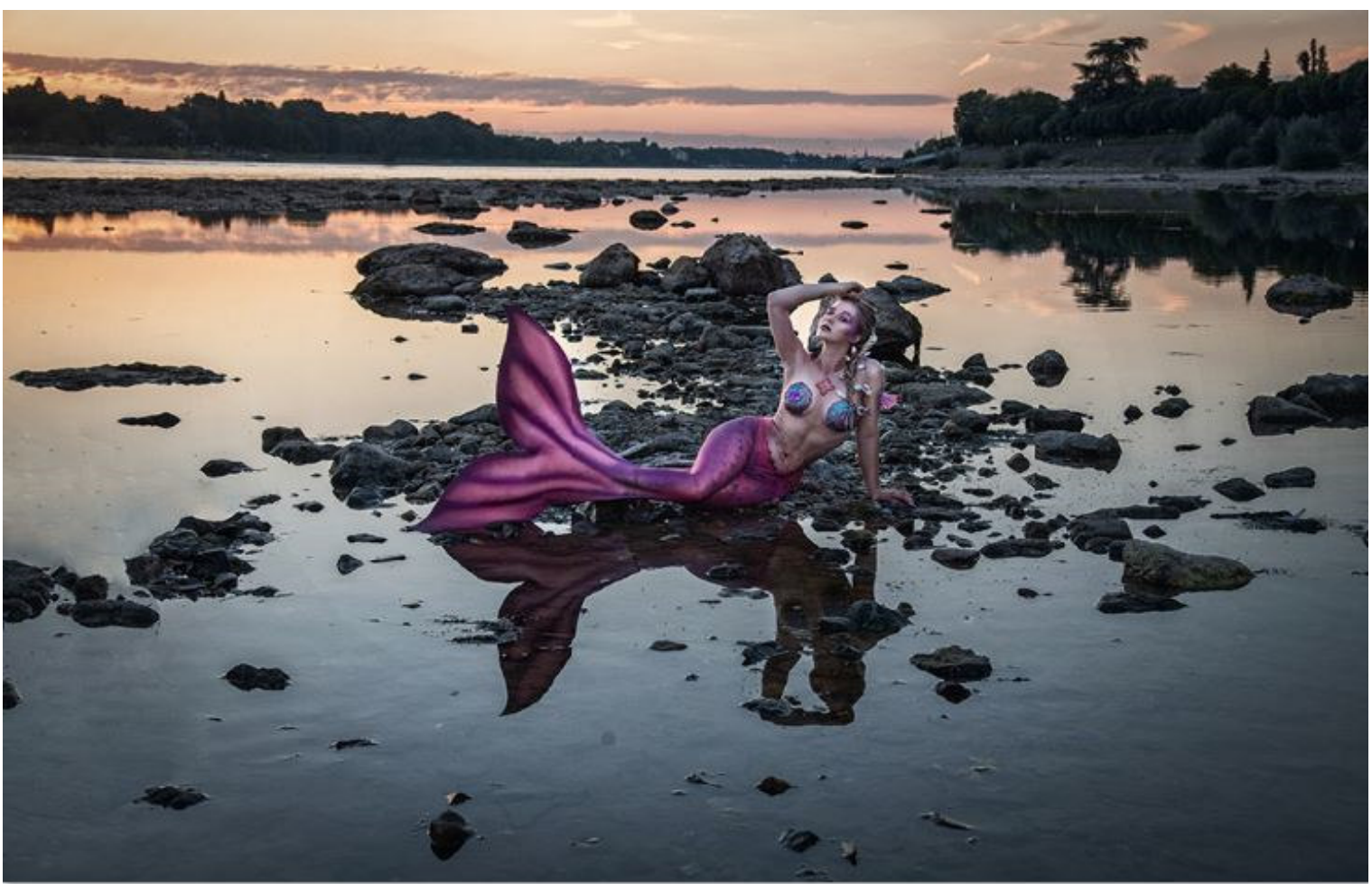

Fig.2: Model Tanja posing as a mermaid, bodypainting by Peter \& Petra Tronser.

\section{2 ...with a fishtail}

Sea creatures exist in numerous mythologies, for example Poseidon, the Greek god of the sea, his Roman counterpart Neptune, or Lord Vishnu's avatar Matsya. Even though those just mentioned are male, one often imagines creatures that are half human, half fish, as female. According to Google, the term "mermaid" appears more than 36 times as often as "merman."

When it comes to the term "mermaid," the German language offers an interesting distinction that I will use in the following: there are "Meerjungfrauen," mermaids which literally translate to "virgins" or "young women of the sea," and "Nixen," which etymologically are traced back to the Latin term "necare = to kill." Thus, there is a fundamental difference in "Meerjungfrauen" and "Nixen," even though they are portrayed very similar or even indistinguishable: as beautiful women usually without legs and feet but instead with a fishtail. However, there are more hybrid creatures of the sea, but I will focus on these two as they were the only ones mentioned in my surveys and I never came across any other type during my participant observation.

The "Meerjungfrau," a character in one of Hans Christian Andersen's fairytales (1837) was adopted by Walt Disney's in 1989. In Andersen's tale, the nameless Little Mermaid "is driven to the surface world by two complementary but separable impulses: a romantic/erotic desire for the handsome prince whom she rescues from drowning in a shipwreck and a moral desire, privileged in Andersen's telling, to attain a soul with the promise of an afterlife" (Hastings 1993, 85). Just as Andersen's mermaid and later Disney's Ariel, "Meerjungfrauen" are imagined as rather gentle and often weak creatures, matching a common observation: "The myth that tells us of the encounter between female creatures connected to the sea or to springs and male conquerors of the sea and builders of dams represents such an imagined world, [...] in categories of femininity and masculinity. In this fantasy, the feminine is imagined as the aquatic, flowing, and the masculine as a force that restrains and channels" 1 (Stuby 1992, 9). Consequently, the "Meerjungfrau" is represented with classical feminine characteristics, representing beauty and grace but also weakness and powerlessness: Ariel, for example, "is silent and passive" (see Mussies 2016, 6). However, in the story of Ariel, there is also a powerful female antagonist. Disney's sea witch Ursula was modelled after the New York Drag Queen Divine. "Ursula falls out of the frame. She is too old, too fat, at the same time excessively feminine and too little feminine, too ugly and from a beauty normative point of view and too powerful. Towards the end of the film we learn that Ursula is able to transform herself into any figure she wants, since towards the end she slips into the body of a beautiful young woman in order to prevent Ariel from marrying Erik. Ursula's thick, excessive body, her non-normative corporeality is thus chosen by

\footnotetext{
${ }^{1}$ „Der Mythos, der uns von der Begegnung zwischen weiblichen Meeres- und Quellwesen und männlichen Meeresbezwingern und Dämmebauern erzählt, repräsentiert eine solche, [...] ausphantasierte, in Weiblichkeits- und Männlichkeitsbilder gekleidete Vorstellungswelt. Das Weibliche wird in ihr als das Aquatische, Fließende imaginiert und das Männliche als Kraft, die eindämmt und kanalisiert.“
} 
herself"' (Frasl 2018, 208f.). Ursula is therefore active and powerful in every respect, even in her choice of appearance. In this way she is closer to the "Nixe."

With the "Nixe," we again encounter an "unsettling hybrid between species" (Barounis 2016, 190): “As mythological sirens, mermaids ("Nixen", the author) are understood to be premodern femme fatales whose feminine allure is fraught with heterosexual peril" (Barounis 2016, 190). Sirens, a specific type of female creatures of the sea, are e.g. known from Homer's Odyssee. In this story the seafaring hero manages to listen to the beguiling songs of the water creatures without being killed by them by letting himself be tied to the mast. To keep his crew members on course, he orders them to clog their ears with wax. Other stories about "Nixen" also emphasize their power over people, primarily over men, which becomes obvious in Goethe's poem "the Fisherman." "Meerjungfrauen" and" Nixen" are similar in some respects - they are beautiful, graceful, and enchanting - in others, however, they constitute complete opposites - here weak and pitiable, there strong and somewhat aggressive. Which one is meant remains vague in model photography.

\section{3 ...with wings}

Winged females can have various forms, they can be birdlike, angelic, or resemble dragons. Creatures with wings have a long history: the Egyptian goddess Isis is often shown with wings, Hermes, the Gods' messenger in the Greek pantheon is said to have worn winged sandals, and then there is Nike, the winged goddess of victory, and Pegasus, the winged horse. It may come as no surprise, however, that angelic figures are particularly present for the models. In biblical descriptions of angels, the writers use masculine pronouns and endow them with male attributes. As higher beings they could also be imagined as sexless - and thus free from desire. Thus, even angels with female features were portrayed without breasts until the 19th century "because angels are purely spiritual creatures $[\ldots]$ there is no sexual difference between them. There are no male or female angels; they are not distinguished by gender" (Daley 2001, 10).

So why did angels "become feminine" in many people's perception? There is only room for speculationpossibly the representations of angels mixed with those of the goddess Nike, who was portrayed in a very similar fashion. It is also conceivable that beauty as an expression of God's power is associated more with women than with men; this may have become naturalized because most authors and artists have been male and heterosexual for centuries. Even to this day, social scientists claim that beauty is rather female than male and that therefore "women face stricter beauty standards that are difficult to achieve [...] as female media images are more often one-dimensional and idealistic" (Goldman and Waymer 2014, 2, see also Ryan 2013, 2).

However, a significant part of the depictions of women with wings can be described as dark or evil angels, some wearing black instead of white wings or wings that resemble dragon wings, some wearing revealing clothes or pose particularly sexy. This also corresponds to everyday observations: among carnival and hen party costumes one often sees evil angels. The theme of the evil/fallen angel has been around for centuries. He is known as Lucifer, which literally translates to "he wo gives light" and usually denotes an angel who plunged into the abyss after he tried to equate himself with God. In some contexts, Lucifer and Satan are identical. Lucifer's "fall had been associated with proud, unlawful insurrection against divine authority. Giving new meaning to this old theme, the Romantic Satanists transformed the fallen angel into a noble champion of political and individual freedom against arbitrary power" (van Luijk 2016, 114). The dark angel is thus associated with self-confidence and rebellion, which is also evident in many representations: Unlike the traditional asexual angels, the models often present themselves as mysterious and erotic angels. Consequently, they draw their strength from two very different and often perceived as opposing sources: eroticism, a very human quality, and divinity, the superhuman.

\section{Embodying hybrid creatures}

props and costumes, and considers how she will embody the figure. The situation of the shooting itself is characterized by the tension between the worry of being caught unfavorably and the hope for good pictures (see Jerrentrup 2018: 41f.) — whereby good pictures do not necessarily mean pretty, attractive pictures. On the one hand, the model takes control of her body by changing it through make-up and costume, perhaps also through image processing, on the other hand, she may feel a loss of control: the static image takes up an isolated, not completely controllable moment, and the images are usually initially in the photographer's and not in the model's possession.

In order to adequately stage the intended role, model and photographer often have to communicate about their emotions, which leads to intimate situations. The performance of the model can often be compared to "method acting", a strategy introduced by Konstantin Stanislawski to draw emotions from one's own horizon of experience when embodying different roles (see Hänßler 2018). This is even more obvious, as the model usually picks topics to which she feels personally related. Against the background of this situation, control and loss of control, as well

\footnotetext{
${ }^{1}$ „Ursula fällt aus dem Rahmen. Sie ist zu alt, zu dick, gleichzeitig exzessiv feminin und zu wenig feminin, schönheitsnormativ betrachtet zu hässlich, zu mächtig. Gegen Ende des Filmes lernen wir, dass Ursula in der Lage ist, sich in jede beliebige Figur zu verwandeln, da sie gegen Ende, um Arielle daran zu hindern, Erik zu heiraten, in den Körper einer schönen jungen Frau schlüpft. Ursulas dicker, exzessiver Körper, ihre nicht-normative Körperlichkeit ist also von ihr gewählt“
} 
as personal expression and acting mix, resulting in a quasi hybrid situation, a situation, that paves the ground for the staging of hybrid creatures. In the following, I will analyse, based on the answers of the survey and my participant observation, why the models are fascinated by embodying hybrid beings.

\subsection{Not fitting in}

The term "hybrid" means "offspring of plants or animals of different variety or species" and derives from the greek hýbris which means "presumption toward the gods" (Online Etymology Dictionary). It was considered one of the worst sins to transgress the limits of one's own conditions. This etymology shows that being hybrid means being between categories, and at the same time, that it can be very brave.

Being staged as a hybrid makes the model act out this feeling of "not fitting in"(see Mussies 2016, 8) and along with it the feeling of being rejected: numerous experiments in favouring in-groups, starting with the famous minimal group paradigm, have shown how difficult and frustrating it can be to be considered an outsider. This reminds on Ariel, "the innocent girl having no voice heard by the others, expecting to be accepted" (Akgün Comak and Pembecioglu 2018, 164) and thus "remains something non-human, representing something very human" (Mussies 2016, 3), the desire to belong to a group while knowing at the same time that one does not fit.

Yet, the hybrid creatures show that there is beauty in being different: the three discussed genera of hybrids are imagined to be graceful, elegant, sexy, or beguiling. Thus, not belonging becomes something worth striving for, something brave, or at least something acceptable. Furthermore, the beauty of hybrid beings also has the power to influence others. Power can also be used for evil, so that hybrid can also represent the individual's dark side or, more generally, the freedom to choose (e.g. Maleficient, Farsl 2018, 219).

\subsection{Oppression}

Exerting her power, the hybrid can be seen as fighting against oppression, especially against the oppression of females, as the hybrids discussed are mostly imagined as females. This leads to a deeply rooted opposition in our society: "In Western patriarchal culture, both women and nonhuman nature have been devalued alongside their assumed opposites-men and civilization/culture" (Kemmerer 2011, 15). One can even go one step further when looking at the association of women and nature: "Women are not merely likened to animals in order to devalue and undermine them. They are silenced by being turned into animals, unable to speak words" (Lane 2019, 107). The link between women and nature, the portrayal of hybrid creatures can also stand for the oppression and destruction of the environment (see Hatfield and Dionne 2014, 81). Ecofeminism comes to mind which dates back to the 1970s and raises "awareness about interconnections between women's oppression and nature's domination in the attempt to liberate women and nature from unjust subordinations" (Yang 2018, 3), an increasingly virulent topic.

However, it is obviously wrong to imagine that people, be it men or women, can overcome nature: "Man is a creature of nature, insofar as he is his (biological) body, and he is a creature of culture, insofar he (by socialisation), has his body" (Gugutzer 2015, 15). Thus, men and women, and even hybrids can be understood as creatures of both nature and culture. The nature/culture and "man/woman dualism is used as justification for exploitative attitudes and actions of men toward women" (Mickey 2018, xx). Playing a hybrid creature, women can distance themselves from the oppressive patriarchal system to which they no longer belong, but at the same time seem to give in: in Disney's version of the Little Mermaid, for example, "Ariel does not have any power and ends up marrying a guy she barely knows [...] so she is just trading one form of patriarchy for another" (Mussies 2016, 5f.).

This can be also interpreted as a trial for upward mobility: Ariel wants to belong to a "better" species. At least in Andersen's original version, this wish must remain unfulfilled and one could conclude: different life forms must not mix - a very conservative message. But even within a species, there are clear rules. In order to get the mermaid's voice, the sea witch Ursula, who turns Ariel into a woman, says: "You will have your looks, your pretty face [...] The men up there don't like a lot of blabber or babble." Ariel learns that her gender is not a natural category, but performative (see Frasl 2018, 211). Towbin and his colleagues conclude, that "to win the love of the prince, she must forfeit her thoughts and intellect, her independence and identity" (Towbin et al. 2008, 38) and even the prince himself quickly adjusts to Ariel's lack of voice.

The deer, mute by nature and typically an object of male desire, is hunted by men, and ultimately killed, the antlers used as a trophy. The same can be assumed for fishes, they are eaten or serve as decoration, and winged creatures often end up in cages. Following this line of thought, all these creatures can stand for the consciousness of oppression, perhaps also for masochistic pleasure, but not for a direct rebellion.

It is different with the enchanting but dealy "Nixe," and also Disney's Maleficent is everything but submissive: wearing her black, shiny dress, she is portrayed similarly to a dominatrix. Beautiful without a doubt, she seems strangely artificial. Even though she has horns that can be seen as a link to nature, her black outfit and pale white skin distance her from what could be assumed as "natural". Further, she is characterized by traits that are assumed as masculine, being pictured as tall, with sharp features - and as her story confirms, she rises up against oppression. 
There are also parallels to the depiction of Lucifer. Angels, in general, might stand for the godly and patriarchal order and therefore stick to the rules, but fallen angels are just the opposite. Consequently, it might not be astonishing that there is a connection between Satanism and political rebellion: "From a political perspective, as we have seen, the nineteenth-century poets singing paeans to Satan were almost invariably 'Leftist' or 'Radical', combining a progressive belief in social and political reform with strongly anti-Christian or anticlerical attitudes. The devil, in the most important of their myths, became strongly associated with the emancipating and liberating tendencies of the Western Revolution" (van Lujik 2018, 114). However, there are more connotations to the fallen angel: as erotic costumes show, the fallen angel is also sexually charged. The combination of angels and sex appears as sacrilege and blatant violation of tradition - and perhaps that is why it is so attractive.

However, the general fascination for hybrid beings in connection to a form of rebellion begins very early in life: Linda Knight uses her young daughter's drawings of hybrid creatures as a type of 'data' to prompt her "to think about childhood resistance to governance and control and how children can object to this hyper-management in conceptual ways" (Knight and Rayner 2015, 91). Consequently, the representation and embodiment of hybrid beings is often associated with the consciousness of oppression or rebellion against it.

\subsection{Sexuality}

As just addressed, sexuality often comes into play when thinking about hybrid beings and they have been linked to intersex subjects: cultural representations of intersex subjects and hybrid creatures "have in common, throughout history, a profound anxiety of the unknown, the other-than-human, the transgressive, of that which resists bodily, speciesist and/or gendered unity by exceeding boundaries of the body and identity" (Amato 2016, 192).

The mermaid, for example, is "male-driven and privilege, power, oppression, and sexual intrusion are all present within the fairytale as well as the film. At the same time, there is a hidden layer of LGBTQ+ traces" (Mussies 2016, 8), in Andersen's motivation to write the story - he had to cope with his unfulfilled love to another man-as well as in the text itself, and even in Disney's depiction of Ursula that was inspired by a famous drag queen. Thus, the mermaid can also be understood as a statement about gender relations.

The hunting and eventual taming of the deer can be equated with the taming of a wild woman or with the transition from childhood to womanhood initiated by intimate relationships to men. Wearing horns, the respective woman is still untamed and thus eventually more interesting to men, to become their trophy. However, the horns are actually associated with masculinity which can be interpreted as a transgender aspect. These are also present in Maleficent as mentioned above. The winged woman depicts the whole spectrum from the asexuality of a traditional angel to transgender to blasphemous sexuality as in fallen angels.

Hence, the staging of hybrid creatures can also stand for a variety of gender identities and sexualities; embodying them can be connected with the confrontation with one's own sexuality: "Being a creature of the sea, I can celebrate my otherness", wrote the trans-person who took part in the survey-obviously avoiding the term "mermaid" or "merman."

\subsection{Salvation}

Andersen's Little Mermaid “is driven to the surface world by two complementary but separable impulses: a romantic/erotic desire for the handsome prince whom she rescues from drowning in a shipwreck and a moral desire, privileged in Andersen's telling, to attain a soul with the promise of an afterlife" (Hastings 1993, 85) - in the end, "even though the romantic/erotic narrative is frustrated, the 'higher' narrative of moral progress remains a possibility" (Hastings 1993, 85, see also Mussies 2016, 2). Andersen's fairy tale offers salvation through body transcendence: "Trust in God's design, and you will fare well, even if you should die" (Zipes 2013, 133). In Disney's version, the body can also be overcome, even though it takes pain and sacrifice, Ariel can become whatever she wants to be. However, here, a physical body remains in the spotlight.

Furthermore, the combination of a female and an animal body can be interpreted as reconciliation with nature. Looking at the hybrid with horns/antlers, the woman wears a signifier for nature, but at the same time, the way she is portrayed is usually highly cultured - with embellishments, decorations, and intricate dresses. Often, there is a resemblance to tribal cultures, or at least to the "western" imagination of tribal cultures. The fascination for the so-called "exotic" has a long history dating back to photographs taken in the colonies fuelling the "western" fantasy, to the presentation of humans of different physique in ethnological expositions, to the Hippies of the 60ies and 70ies, and today's Boho movement, integrating aspects of "exotic" cultures in their own look, music, interior decoration, etc. (see Mercer 1987, 119). Around the Millennium "the invocation of tribal culture by "modern primitives' and neo-tribals, gave new meaning to images of the primitive [...] Coffee-table books displaying illustrated bodies from around the world [...] often emphasize the exotic and offer minimal analysis, yet they still serve as references for revival movements and contemporary practices" (Schildkrout 2004, 327). These books not only show foreign people's physique and dress but also rituals and spiritual aspects. Edward Said prominently criticised the "western" tendency to orientalise the "other" and to impose own ideas and dreams on everything foreign, thus to mentally re-colonialize the "orient" which is a fuzzy mental construct itself (Said 1978). From the 
perspective of the "west" such motifs can stand for a deficit experience, for a longing for clear structures, unambiguous identity, and spirituality (see Jerrentrup 2019), an existence that is portrayed as more fulfilling than the typical "western" everyday life.

However, the aspect of salvation becomes particularly obvious with regard to winged beings: Similar to Jesus, the angel mixes a human appearance with a divine figure. The fallen angel, on the other hand, can be seen as a metaphor for independent, free action, for finding salvation in the overcoming of the traditional system.

\section{Conclusion}

"You can be whatever you want," one participant of my survey explained her fascination with hybrid beings. Embodying a hybrid creature can not only imply a statement about society, but also means crossing the limits of the own body, even more, physical limits in general. This transcendence of the body does not only take place in cyberspace as it is typical for our times (see Lackner 2014, 95f.), but can be experienced in one's own body. As such, it might go deeper and can be understood as an empowerment: transforming oneself into a hybrid being and identifying with it can turn perceived disadvantages - looking different, not fitting in, feeling deprived-into strengths and can even show, that the body is not the limit, but with the help of make-up, costume, props, Photoshop, and imagination, the person can overcome her own body.

Such a process was described by one of the participants in my survey with these words: "Since it is described in 'The Little Mermaid' that every step she takes feels like a step into knife blades, I could increasingly identify with her as my disability got worse. For me, it is exactly the same; actually, I can walk, but if I want to use my legs, I have to bear this stabbing pain with every step. That is the sacrifice of having legs. That is why I like to wear the fin in my wheelchair. I can't walk without pain anyway, so I can also wear the fin."

Whereas the pain described is physical, the same could be true for emotional pain. The positive side was stressed in comments like "it makes me feel more self-confident" or when the feelings of "defensiveness, selfefficacy and magic through being extraordinary" were mentioned.

"Our response to the world is essentially imaginative: that is, picture-making. We live in our pictures, our ideas. I mean this literally. We first construct pictures of the world and then we step inside the frames" writes Salman Rushdie (1992, 377f.), whose figures celebrate supposedly "blasphemous" hybridity. Similarly, the models create an image of the hybrid, adapt, replicate, and change it. This way, myths that fit post-modern needs can develop. The best example is probably Maleficent who is also the most hybrid creature - a humanoid with horns and, at least in the beginning and in the end, with wings, and both good and evil.

\section{References}

Aaron (2001), "Top 10 Horned Girls in Anime", https://honeysanime.com/top-10-horned-girls-in-anime/ Accessed 12.06.2020

Akgün Comak, Nebahat and Nilüfer Pembecioglu (2018), "The Mystical Heroic Symbol of the $21^{\text {st }}$ Century: The Mermaid As The Symbol Of Charm And Secrets In Different Cultures", $7^{\text {th }}$ Annual International Conference on Journalism and Mass Communications.

Amato, Viola (2016), "Reimagining Intersex: Literary Renegotiations of the Dis/Continuities between Hegemonic Narratives and the Recognition of 'Difference' in Intersex Narratives. Shifts in the Representation of Intersex Lives in North American Literature and Popular Culture Book". Bielefeld: Transcript Verlag.

Athanassglou-Kallmyer, Nina (2018), "Ugliness". In On the Politics of Ugliness edited by Sara Rodrigues and Ela Przybylo. Cham: Palgrave MacMillan. 31-50, 2018.

Barounis, Cynthia (2016), "Mermaids, Prosthetics, and the Disabling of Feminine Futurity", Women's Studies Quarterly, 44, 1/2, SURVIVAL issue, 188-204.

Barsalou, Lawrence W., Paula M. Niedenthal, Aron K. Barbey and Jennifer A. Ruppert (2003), "Social Embodiment", in: The Psychology of Learning and Motivation. Advances in Research and Theory edited by Brian H. Ross. Amsterdam: Academic Press, 43-91.

Eryne, Eleanor and Marin McQuillan (1999): "Deconstructing Disney", London: Pluto Press.

Busatta, Sandra (2016), "Donne pericolose: Donna Doppia, Donna Cerva, Donna Gialla e le alter", Forma Vrbis, XXI (3),30-37.

Daley, Michael J. (2016), "Catholic Questions, Wise Answers”, Cincinnati: Anthony Messenger Press.

Darwin, Helana (2017), "Doing Gender Beyond the Binary: A Virtual Ethnography”, Symbolic Interaction, 40 (3), 317-334.

Frasl, Beatrice (2018), “Team Maleficient - Das Monströse Weibliche und/als das Monströse Queere bei Disney“, in Doing Space while Doing Gender. Vernetzungen von Raum und Geschlecht in Forschung und Politik edited by Aenne Gottschalk, Susanne Kersten and Felix Krämer. Bielefeld: Transcript, 201-222.

Gartziou-Tatti, Ariadne, Panayotis N. Soucacos and Minas Paschopoulos (2017), "Introduction", in Hybrid and Extraordinary Beings. Deviations from "Normality" in Ancient Greek Mythology and Modern Medicine. Athens: Konstandaras Editions, vii-xv. 
Gogol, Nikolai (2003), “The Night before Christmas in The Collected Tales of Nikolai Gogol, translated by Richard Pevear and Larissa Volokhonsky", London: Granta.

Goldman, Adria and Damion Waymer (2014), "Identifying Ugliness, Defining Beauty: A Focus Group Analysis of and Reaction to Ugly Betty", The Qualitative Report, 19 (10), https://nsuworks.nova.edu/cgi/viewcontent.cgi?article=1263\&context=tqr

Gugutzer, Robert (2015): Soziologie des Körpers. 5th reworked edition. Bielefeld: Transcript.

Hänßler, Boris (2018), „Die Seele auf der Buehne“, Psychologie Heute.. https://www.borishaenssler.de/artikel/die-seele-auf-der-buehne/ Accessed 12.06.2020

Hastings, Waller A. (1993), "Moral Simplifications in Disney's The Little Mermaid", Lion and the Unicorn, 17( 1): 83-92.

Hatfield, Joe and Jake Dionne (2014), “Imagining Ecofeminist Communities via Queer Alliances in Disney's Maleficent", Florida Communication Journal, 42, 2, 81-98.

Herzfeld, Michael (1984), "The horns of the Mediterraneanist dilemma", American Anthropologist, 11(3), 439454.

Jerrentrup, Maja Tabea (2018), „Therapie vor der Kamera. Zum Potential inszenierter Menschenfotografie,. Münster: Waxmann.

Jerrentrup, Maja Tabea (2019), „Der ,Orient“ in der inszenierten Porträtfotografie“, Pop Zeitschrift. www.popzeitschrift.de/2019/08/19/der-orient-in-der-inszenierten-portraitfotografievon-maja-tabea-jerrentrup19-82019/

Kemmerer, Lisa (2011), "Sister Species. Women, Animals and Social Justice", Chicago: University of Illinois Press.

Knight, Linda and Hannah Rayner (2015), "Hybrid creatures as complicating visions of early childhood", Complicity: An International Journal of Complexity and Education, 12(1), 86-97.

Lackner, Thomas (2014), „Computerspiel und Lebenswelt: Kulturanthropologische Perspektiven“, Bielefeld: Transcript.

Lane, Cathy (2018), "Women as animal, women as alien: Reclaiming women's demonic voices",in Grounds for Possible Music: On Gender, Voice, Language, and Identity edited by Julia Eckhardt. Berlin: Errant Bodies, 106-111.

MacDorman K. F. and S. Entezari (2015): Individual differences predict sensitivity to the uncanny valley. Interaction studies, 16 (2), 141-172.

Mercer, Kobena (1987), "Black hair/style politics", in Black British Culture \& Society. A Text Reader edited by Owusu, Kwesi. London and New York: Routledge, 111-121.

Mickey, Sam (2018), "Editor's foreword", in Women and Nature? Beyond Dualism in Gender, Body, and Environment edited by Douglas A. Vakoch and Sam Mickey. New York: Routledge.

Miller, Carl (2014), “ The Promise of social media”, Demos Quarterly, 5 (0), http:/quaterly.demos.co.uk/article/issue-1/the-promise-of-social-media/ Accessed 12.06.2020

Mussies, Martine (2016), "The Bisexual Mermaid: Andersen's fairy tale as an allegory of the bi-romantic sexual outsider", Full-text of a presentation at EuroBiCon on the 30th July 2016.

Naumov, Goce (2013), "The Objectified Corporeality: Prehistoric Implications of Anthropomorphism and Hybridism within Christian Iconography", Anthropos, 108 (1), 97-115.

Rushdie, Salman (1992), “Imaginary Homelands. Essays and Criticism 1981-1991”, London: Granta Books.

Russell, Jeffrey Burton (1977), "The Devil. Perception of Evil from Antiquitiy to Primitive Christianity". Ithaca and London: Cornell University Press.

Ryan, Elin (2013): Is Ugly the New Beautiful? An Investigation of Perceptions of Beauty by Young Female Viewers ofUgly Betty in the US. Mass Communication and Journalism, 3 (3).

Said, Edward (1978), "Orientalism”, New York: Pantheon Books.

Schildkrout, Enid (2004), "Inscribing the body", Annual Review of Anthropology, 33, 319-344.

Stuby, Anna Maria (1992), „Liebe, Tod und Wasserfrau. Mythen des Weiblichen in der Literatur“, Wiesbaden: Westdeutscher Verlag.

Tajfel, Henri and John C. Turner (1986), "The social identity theory of intergroup behaviour", in Psychology of intergroup relations edited by S. Worchel and W. G. Austin. Chicago: Nelson-Hall, 7-24.

Towbin, M.A., S.A. Haddock, T.S. Zimmerman, L.K Lund and L.R. Tanner (2008), "Images of gender, race, age and sexual orientation in Disney feature-length animated film", Journal of Feminist Family Therapy, 15( 4), 19-44.

Van Lujik, Ruben (2016), “Childern of Lucifer: The Origins of Modern Religious Satanism”, New York: Oxford University Press.

Yang, Karen Ya-Chu (2018), "Introduction", in Women and Nature? Beyond Dualism in Gender, Body, and Environment edited by Douglas A. Vakoch and Sam Mickey. London and New York: Routledge, 3-9.

Zipes, Jack (2013), “When Dreams Came True: Classical Fairy Tales and Their Tradition”, New York: Routledge. 